\title{
Role of Enset (Ensete ventricosum (Welw.) Cheesman) in Soil Rehabilitation in Different Agro-ecological Zones of Hadiya, Southern Ethiopia
}

\author{
Chakoro Tamire ${ }^{1}$, Mekuria Argaw ${ }^{2}$ \\ ${ }^{1}$ Environemntal Management Team, Ethiopian Railways Corporation/ERC, Addis Ababa, Ethiopia \\ ${ }^{2}$ Center for Environmental Science, Addis Ababa University, Addis Ababa, Ethiopia
}

Email address:

oronurebo@gmail.com (C. Tamire),m_argaw@yahoo.com (M. Argaw)

\section{To cite this article:}

Chakoro Tamire, Mekuria Argaw. Role of Enset (Ensete ventricosum (Welw.) Cheesman) in Soil Rehabilitation in Different Agro-ecological Zones of Hadiya, Southern Ethiopia. American Journal of Environmental Protection. Vol. 4, No. 6, 2015, pp. 285-291.

doi: 10.11648/j.ajep.20150406.14

\begin{abstract}
Soil degradation is a problem both in developed and developing countries. Its impact is of great concern to farmers that depend on rain fed agriculture. The objective of this research was to assess the role of enset in soil rehabilitation. Household survey and soil quality analysis were conducted to collect primary data from the fields. Soil laboratory analysis result revealed that enset field had significantly $(\mathrm{p}<0.05)$ higher level of TN $(0.3 \%)$, OC (3.6\%), Av. P (66.7ppm) and lower level of BD (1.2) than annual crop fields. This might be due to the materials added to the soil from the plant parts and organic farming (application of manure and domestic waste). Enset has highly degradable parts such as leaf midribs, pseudostem sheath, pseudostem core/ which are used to maintain soil fertility. Laboratory analysis of soil has shown that an average size of clay, silt and sand fraction under enset cultivation was $31.2 \%, 49.3 \%$ and $19.5 \%$, respectively, while in the annual crop land the proportion of clay, silt and sand were $37.5 \%, 40.3 \%$ and $22.2 \%$, respectively. The mean value of TN and OC were found to be greater in dega than the $w /$ dega and dry w/dega zones of agro-ecology. The overall output from the research showed that enset has contribution in environmental rehabilitation.
\end{abstract}

Keywords: Agro-ecology, Enset ventricosum, Soil Rehabilitation

\section{Introduction}

The rehabilitation of degraded soil and water resources will be critical in meeting future global food demand in the context of future climate variability and in addressing associated negative impacts on the environment that are a consequence of current agricultural systems. At the global level, combating soil degradation (soil rehabilitation) will help offset greenhouse gas emissions, provide a better environment, guarantee more food to an increasing population, and contribute to the economic progress of future generations [2]. However, in Ethiopia there is practice of rehabilitating the degraded low-potential areas mainly by construction of physical soil and water conservation structures along with tree planting on hillsides [5].

Ensete venticosum is a monocot perennial crop that belongs to order Schistaminae, family Musaceae and genus Enset. Genus enset has different species, but there is some ambiguity regarding their numbers. However, all authors agree that Ensete ventricosum is the only cultivated species in Ethiopia.
It looks like a large, thick single stemmed banana like plant [14]. Usually it is larger than banana and 6-12 meters tall. The leaves are 5-7 meters tall and 1 meter in diameter and are more erect than a banana plant [18]. The stem has three parts. The pseudo-stem, which is made of tightly clasping leaf sheaths, is 2-3 meters in height and which are average of 1 meter diameter. The underground corm is an enlarged lower portion of the stem with an average of 0.7 meter length. The true stem is between the pseudo-stem corms near the ground. Usually it grows up during maturity and initiates a single flower head, which forms multiple flower fruits and seeds [18].

In land point of view, fertility is suitable for an environment for production and in which the climate and the soil are the main components [13]. Soil fertility is made up of three important properties (physical, chemical and biological) that greatly influence the soil's suitability for production. According to this, some parameters of soil fertility are total nitrogen, phosphorous, organic carbon, $\mathrm{pH}$, bulk density and some others. According to this, some parameters of soil fertility are 
discussed below which are used to study soil rehabilitation.

Total nitrogen measures the total amount of nitrogen present in the soil, much of which is held in organic matter and is not immediately available to plants. It may be mineralised to available forms. It composed of inorganic $\left(\mathrm{NH} 4+, \mathrm{NO}^{-}\right.$and $\mathrm{NO} 2{ }^{-}$) and organic forms (OM) are subject to change due to various factors. Management (cropping, fertilization, erosion and leaching) and climate (temperature and moisture) determine its level and dynamics [8]. Climatic conditions, especially temperature and rainfall generate dominant influence on amounts of nitrogen and organic matter found in soils. As one moves from warmer to cooler zones, the organic matter and nitrogen contents of comparable soils tend to increase [14].

Phosphorus forms the most critical essential element in influencing plant growth and production across the world. Unlike nitrogen, it is not supplied through biochemical fixation but must come from other sources to meet plant requirements [14]. The sources include commercial fertilizer, animal manure, plant residues, human, industrial and domestic wastes and native compounds of phosphorus. Hence, its deficiency is directly related to food security issues, especially in the tropics where severe soil degradation is responsible for serious deterioration in soil quality $[7,12]$.
Soil organic carbon is important for the function of ecosystem and agro-ecosystems having a major influence on the physical structure of the soil, the soil's ability to store water (water holding capacity), and the soil's ability to form complexes with metal ions and supply nutrients. Loss of SOC can, therefore, lead to a reduction in soil fertility, land degradation and even desertification. Hence, the purpose of this research was to asses the role of enset in soil rehabilitation at the time of climate related hazard has occurred.

\section{Materials and Methods}

\subsection{The Study Area}

Hadiya zone is one of the zones of southern nations, nationalities and peoples region. It is situated roughly at the margin of the great Ethiopian Rift Valley at western margin in north western part of SNNPR. It located between $7^{0} 07^{\prime}-7^{0} 92^{\prime} \mathrm{N}$ and $37^{\circ} 29^{\prime}-38^{\circ} 13^{\prime} \mathrm{E}$. The zone bordered in East and North East with Alaba Special Wereda and Siliti Zone, respectively. In the North it bordered with Kembata Tembaro, in the South East it is bordered with Oromiya region. Hossana is the capital city of the zone and it is $232 \mathrm{~km}$ away from Addis Ababa.

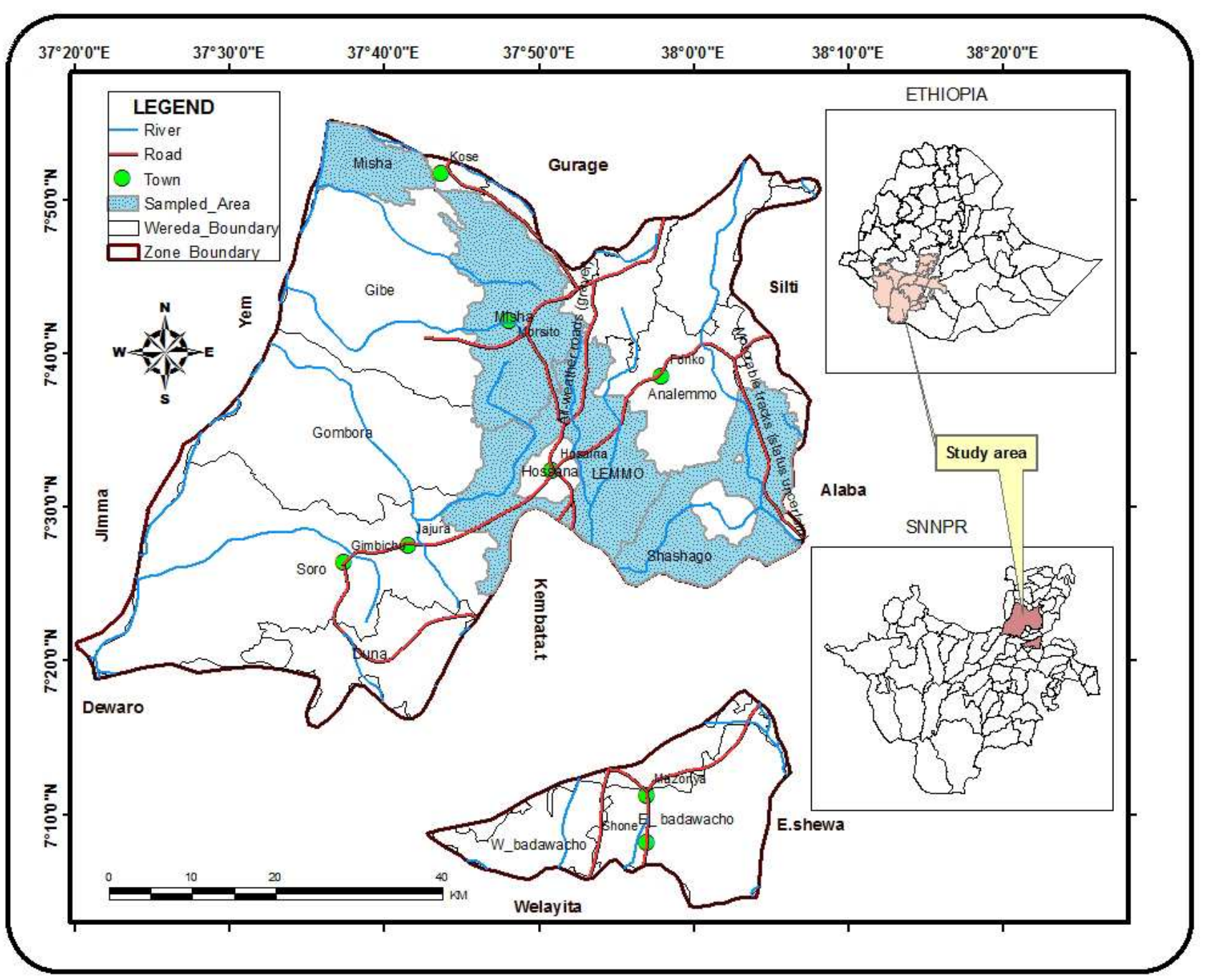

Figure 1. Map of the study area. 
Topography of the zone is sloppy (54\%) and flat (46\%) out of the total land [22]. The altitudinal variation between the average highest peak and the lowest point ranges from $3200 \mathrm{~m}$ at Tulla in Misha district and $860 \mathrm{~m}$ at Gortancho and Gibe valley in Soro district, respectively.

\subsection{Soil Sampling and Laboratory Analysis}

In order to see whether enset contributes towards the rehabilitation of degraded land through soil fertility improvement, soil samples were taken and analysed.

The soil samples were taken from annual crop fields and enset field from dega, woina dega and dry/w/dega AEZs. Equal numbers of soil sample (i.e.15) were taken from each field. At each sampling field five sub samples were collected by using soil auger at depth of $0-30 \mathrm{~cm}$. The five soil samples were mixed of which $1 \mathrm{~kg}$ of composite soil sample was taken for laboratory analysis.

The collected samples were analysed at Holeta Agricultural Research Center. Finally, the following soil parameters analysed: soil reaction $(\mathrm{pH})$, organic carbon $(\mathrm{OC})$, total nitrogen (TN), available $\mathrm{P}$ (Av. P), bulk density (BD) and soil texture. These physicho-chemical soil parameters were analysed using a standard methods. The total nitrogen content in soils was determined using the Kjeldahl procedure by oxidizing the organic matter with sulphuric acid and converting the nitrogen into ammonium. Then ammonium was determination in the digest. Soil $\mathrm{pH}$ was determined by potentiometric method at soil to water ratio of 1:2. Organic carbon (OC) was determined by Walkley Black Method.

Depending on soil $\mathrm{pH}$ of the available phosphorous was determined by Olsen method. The soil texture was determined by the Bouyoucos Hydrometer method it was calibrated at $67^{0} \mathrm{~F}$ to read directly in grams or percentage material remaining in suspension with a fixed amount of soil. The bulk densities of the soil sampled were estimated by taking undisturbed soil by core sampler after drying the soil samples in an oven at $105^{\circ} \mathrm{C}$ to constant weights. In addition to this the researchers were used house hold survey, key informants interview and field observation.

\section{Results and Discussion}

The field survey report and soil laboratory analysis showed that enset has a role in soil rehabilitation. What was observed in the study area is that, continuous cultivation of crop without using any conservation measure in annual crop land; and climate related hazards (drought and runoff) has negative effect on the land. This practice might lead to soil erosion and soil nutrient depletion hazard, which further enhanced the land for declined crop productivity and food insecurity.

People of Hadiya have rehabilitated the soil by cultivating enset crops near the households. Because of its farming system (organic farming), protecting of soil from evapotranspiration by broad leaves (canopy), water holding and releasing properties to the soil, that increase the fertility of the soil.

\subsection{Effect of Enset in Chemical Properties of Soil}

Some chemical parameters such as total nitrogen (TN), organic carbon (OC), available phosphorus (Av. P) and soil reaction $(\mathrm{pH})$ of soil were used to describe the contribution of enset by comparing with annual crop fields, and with the general standards. The results obtained to evaluate the effect of enset on soil chemical properties are presented in table 1 below.

Table 1. Mean values \pm SEM of soil chemical properties under the enset and annual crops.

\begin{tabular}{|c|c|c|c|c|c|}
\hline \multirow{3}{*}{ No } & \multirow{3}{*}{$\begin{array}{l}\text { Soil } \\
\text { parameters }\end{array}$} & \multicolumn{4}{|c|}{ Mean value and rank } \\
\hline & & \multicolumn{2}{|l|}{ Enset } & \multicolumn{2}{|l|}{ Annual crop } \\
\hline & & Mean value & Rating & Mean value & Rating \\
\hline 1 & $\mathrm{pH} \mathrm{H}_{2} \mathrm{O}(1: 2)$ & $6.94 \pm 0.153$ & Neutı & $6.17 \pm 0.130$ & $\begin{array}{l}\text { Slightly } \\
\text { acidic }\end{array}$ \\
\hline 2 & OC $\%$ & $3.60 \pm 0$ & Very 1 & $2.58 \pm 0$ & High \\
\hline 3 & Av. P (ppr & $66.76 \pm 12.092$ & Very high & $15.16 \pm 3.653$ & Medium \\
\hline 4 & Total N (\%) & $0.30 \pm 0.020$ & High & $0.23 \pm 0.021$ & Medium \\
\hline
\end{tabular}

In addition to the above table the effect of enset in chemical properties of soil in different agro-ecological zones are shown in table 2 below.

Table 2. Mean value \pm SEM of soil chemical properties under the enset in different AEZs.

\begin{tabular}{lllll}
\hline \multirow{2}{*}{ No } & \multirow{2}{*}{ Soil parameters } & \multicolumn{3}{l}{ Mean value } \\
\cline { 3 - 5 } & & Dega & w/dega & Dry w/dega \\
\hline 1 & $\mathrm{pH} \mathrm{H}$ O (1: 2$)$ & $7.18 \pm 0.138$ & $7.27 \pm 0.25$ & $6.36 \pm 0.20$ \\
2 & $\mathrm{OC} \%$ & $4.33 \pm 0.26$ & $4.18 \pm 0.23$ & $2.28 \pm 0.22$ \\
3 & Av. $\mathrm{P}(\mathrm{ppm})$ & $46.20 \pm 8.24$ & $86.28 \pm 30.0$ & $67.80 \pm 17.45$ \\
4 & Total $\mathrm{N}(\%)$ & $0.36 \pm 0.23$ & $0.30 \pm 0.36$ & $0.23 \pm 0.02$ \\
\hline
\end{tabular}

\section{Total Nitrogen/TN}

Total nitrogen is one of the indicators of the fertility status of the soil. According to the soil analysis result, the average value of total nitrogen under enset and annual crop land was $0.3 \%$ and $0.23 \%$, respectively (Table 1 ). Further 'Levene's Test for Equality of variances' in t-test showed significant difference $(\mathrm{t}=2.200$ and $\mathrm{sig}=0.036)$ at $(\mathrm{p}<0.05)$ level between the two groups (under enset and annual crop land) of total nitrogen. Literally the amount of total nitrogen in enset field was greater than annual crop field; this shows that enset has an effect to maintain the amount of nitrogen in the soil.

The laboratory results confirm that enset could rehabilitate the degraded land by increasing important soil nutrients. This might be due to the materials added to the soil from the plant parts and organic farming (application of manure and domestic waste). Enset has highly degradable parts such as leaf midribs, pseudostem sheath, pseudostem core/ which are used to maintain soil fertility.

Their degradability is higher than green chloris gayana, setaria grass, elephant grass and guatemala grass [3]. Therefore, there is a great opportunity to expand enset agriculture, and by it environmental rehabilitation is high [19], leaching and losses of plant nutrient, particularly nitrogen, may be reduced by enset as compared to annual crops. This 
should be possible because of the continuous soil occupation by roots.

Some literature has rate the content (\%) of nitrogen as very high (>0.5), high (0.25-0.5), medium (0.15-0.25), low $(0.05-0.15)$ and very low $(<0.05)$. Based on this, enset land could be classified in the higher rank (Table 1).

The mean value of total nitrogen (TN) was found to be greater in dega than the w/dega and dry w/dega zones of agro-ecology (Figure 2; Table 2). The mean TN content in the zones were $0.36 \%, 0.30 \%$, and $0.23 \%$ for $\operatorname{deg} a, w / \operatorname{deg} a$ and dry $w / \operatorname{deg} a$, respectively (Table 2 ). The mean values of TN content from enset land of the different zones of agro-ecology are shown in figure 2 below.

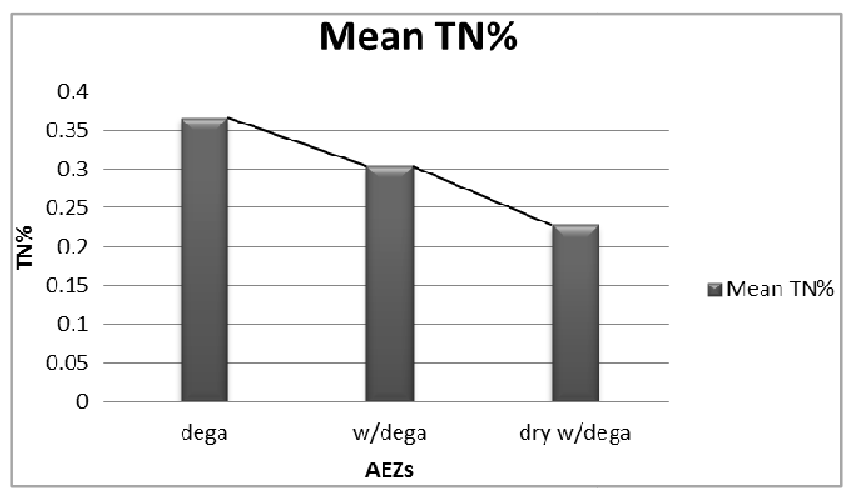

Figure 2. Total nitrogen amount in different AEZs of the study area.

ANOVA result proves that significant difference was observed at $(\mathrm{P}<0.05)$ under the agro- ecological zones from the enset cultivated field. Based on the ANOVA analysis, TN was significantly increasing in highlands (rainfall and elevation is high) than other AEZs. Further the statistical test of LSD verifies that the mean TN content of enset field in dega show positive significant difference from dry w/dega; but no significant difference was found from $w / \operatorname{deg} a$. Even the $w /$ dega had high mean value of TN from dry w/dega; it was not significantly different. However, the mean difference in each consecutive agro-ecological zone was not significant.

The results also confirm that enset has an effect on total nitrogen; as the elevation and coolness increase the coverage and cultivation of enset increase and in turn the fertility also increases. As altitude increases the suitability to enset cultivation also increases and total nitrogen availability increases in a given enset cultivation field. As one moves from warmer to cooler zones, the organic matter and nitrogen contents of comparable soils tend to increase [14].

This might be because of climatic conditions; especially temperature and rainfall which generate dominant influence on amounts of nitrogen and organic matter found in the soils.

Organic Carbon/Organic matter

The mean value of organic carbon was $3.60 \%$ and $2.58 \%$ for enset and annual crop land, respectively (Table 1). The t-test for equality of means verifies that difference between the two mean values were also statistically significant at $(\mathrm{P}<0.05)$. Organic carbon content of the soil under enset was higher which may be related to organic materials incorporated to soil from the plant and application of cattle manure. Soil organic matter consists of roots, plant residues, and soil living or dead organisms [4]. Further enset cultivation attracts most of the organic waste whereby farmers allocate about $80 \%$ of the organic manure and crop residue to the enset and banana fields, including the nutrients coming from outfield in terms of feed and mulch $[11,21]$.

Organic matter has been termed the "life blood" of soils. Pearson correlation analysis in table 19 shows that organic carbon has significantly strong correlation with TN (0.913) and $\mathrm{pH}(0.57)$. It has insignificantly strong correlation with BD (0.69), but week correlation with Av.P (0.273).

It has a tremendous impact and influence upon the chemical, physical and biological properties of the soil, soil fertility status, plant nutrition and biological activity in the soil $[4,14]$. The same to organic carbon the level of the organic matter evaluated using soil organic carbon was higher under enset. Organic matter is calculated from the levels of organic carbon in the soil by multiplying by $1.72[9,16]$. The reason behind the difference of organic matter may be due to framers' management practices in enset plot, where they enrich it with manure and crop residues.

Again the reason for soil organic matter accumulation could be high enset cover in enset land which result litter input and thus higher accumulation of organic matter in the soil. An improvement in organic matter content follow the enset cultivation is important sign of soil restoration. By which both physical and chemical properties of soils can be improved. Some research note that lowering of organic matter may increase soil erosion and degradation, and enhanced greenhouse effect from released CO2. According to [16], organic carbon was classified in rat of very high and high respectively for enset and annual crop land (Table 1). The mean value of organic carbon (OC) was found to be greater in dega than the w/dega and kola or dry w/dega zones of agro-ecology (Table 2).

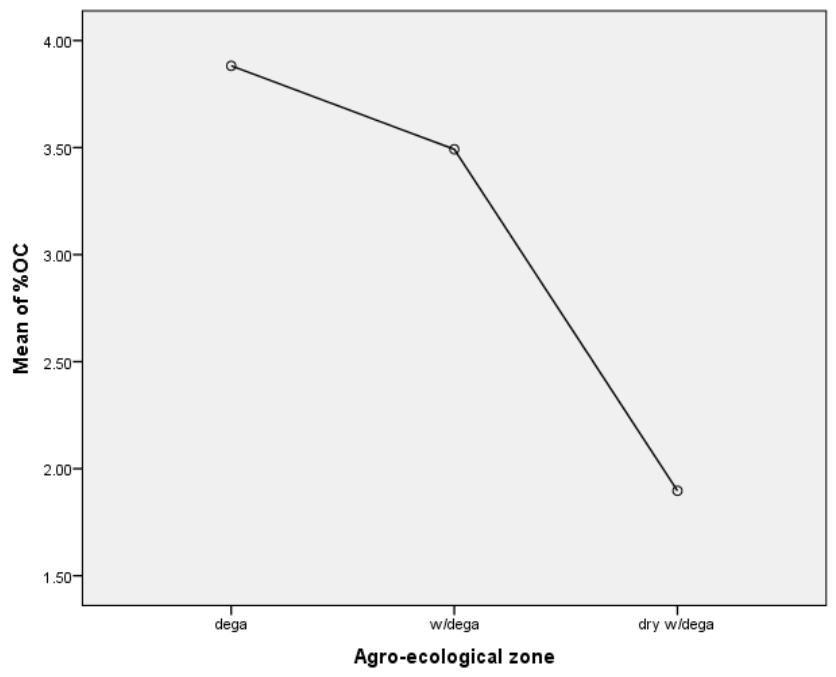

Figure 3. The mean means plots of organic carbon in different AEZs.

ANOVA result proves that significant difference was observed under the agro-ecological zones from enset cultivated field at $(\mathrm{P}<0.05)$. This may be because of climatic 
conditions; especially temperature and rainfall that generate dominant influence on amounts of nitrogen and organic matter found in soils. The mean values of organic carbon content of the different AEZs from enset cultivated fields are shown below in means plot (Figure 3).

The statistical test of LSD verifies that the mean OC content of enset field in dega shows positive significant difference from dry $w /$ dega; but no significant difference was found from $w /$ dega. However, w/dega had significantly high mean value of OC than dry w/dega of enset field. The amount of organic carbon from enset land at dega and $w / \operatorname{deg} a$ has been grouped in to very high ( $>0.3$ ) (Table 2). According to [16], this kind of soil has good structural condition and high stability, and probably water is repellent.

\section{Soil Reaction $(p H)$}

Soil reaction $(\mathrm{pH})$ is one of the soil chemical properties that indicate soil quality in this study. The mean $\mathrm{pH}$ value obtained underneath the enset was 6.94 while that obtained from annual crop land was 6.17 . The t-test for equality of means verifies that difference between the two mean values was also statistically significant at $(\mathrm{P}<0.05)$.

According to [15], $\mathrm{pH}$ of the soil from the enset and annual crop land was nearly neutral and slightly acidic, respectively. This $\mathrm{pH}$ range is preferable for many crops [16]. Therefore, enset cultivation is important to moderate the soil to the crops.

\section{Available Phosphorus}

Next to nitrogen, phosphorus is the most critical essential element in influencing plant growth and production across the world. Laboratory result of soil analysis further revealed that the mean available phosphorus was $66.76 \mathrm{ppm}$ and $15.16 \mathrm{ppm}$ for enset land and annual crop land, respectively (Table 1). Independent sample t-test proves that enset land has significantly high Av. P mean value than annual crop land at $(\mathrm{P}<0.05)$ level. The increased mean Av.P value at enset land was compared to that of the annual crop cultivated land probably due to the applications of organic materials such as manure, plant residues. This might show that enset crop cultivation has an effect to increase Av. P in its field.

Mulching and the addition of organic matter to the soil can keep phosphorus from becoming bound to aluminium and other ions in acid soils, thus making it more available for plants [10]. Its sources include commercial fertilizer, animal manure, plant residues, human, industrial and domestic wastes and native compounds of phosphorus. Hence, its deficiency is directly related to food security issues, especially in the tropics where severe soil degradation is responsible for serious deterioration in soil quality $[7,12]$.

According to study conducted by [6], whole farm nutrient flow analysis by farmers, and yield variability across the farm units in the area indicated that there was a positive nitrogen and phosphorus balance, while the outfields indicated extremely low nitrogen and phosphorus balances for all farmers of various social categories.

Table 17 shows that the mean values of Av.P for dega, $w / \operatorname{deg} a$ and dry $w / \operatorname{deg} a$ were $46.2 \mathrm{ppm}, 86.28 \mathrm{ppm}, 67.8 \mathrm{ppm}$, respectively.

However, multiple comparison tests using the tamhane showes that, no significant difference in each agro-ecological zone. This could shows that phosphorus in the w/dega enset field is more available for crop than other AEZs.

\subsection{Effect of Enset in Physical Properties of Soil}

The soil physical properties are one of the soil quality indicators that may be changed through enset cultivation. For this study bulk density and soil texture were taken as a physical indicator of soil fertility. The results obtained to evaluate the effect of enset on soil physical properties are presented in table 3 below.

Table 3. Mean values \pm SEM of soil physical properties under the enset and annual crops.

\begin{tabular}{|c|c|c|c|c|c|}
\hline \multirow{3}{*}{ No } & \multirow{3}{*}{$\begin{array}{l}\text { Soil } \\
\text { parameters }\end{array}$} & \multicolumn{4}{|c|}{ Mean value and Rank } \\
\hline & & \multicolumn{2}{|l|}{ Enset } & \multicolumn{2}{|c|}{ Annual crop } \\
\hline & & Mean value & Rating & $\begin{array}{l}\text { Mean } \\
\text { value }\end{array}$ & Rating \\
\hline 1 & $\mathrm{BD}$ & $1.2 \pm 0.03$ & Low & $1.3 \pm 0.03$ & Low \\
\hline 2 & Texture & - & $\begin{array}{l}\text { Silt clay } \\
\text { loam }\end{array}$ & - & $\begin{array}{l}\text { Clay } \\
\text { loam }\end{array}$ \\
\hline
\end{tabular}

In addition to the above table the effect of enset in physical properties of soil in different agro-ecological zones are shown in table 4 below.

Table 4. Mean value $\pm S E M$ of $B D$ and soil texture under the enset in different AEZs.

\begin{tabular}{lllll}
\hline \multirow{2}{*}{ No } & \multirow{2}{*}{ Soil parameters } & Mean value & & \\
\cline { 3 - 5 } & & Dega & w/dega & Dry w/dega \\
\hline 1 & BD g/cm & $1.26 \pm 0.24$ & $1.12 \pm 0.07$ & $1.22 \pm 0.03$ \\
1 & Clay $\%$ & $34.5 \pm 2.76$ & $28.0 \pm 1.23$ & $40.5 \pm 2.62$ \\
2 & Silt $\%$ & $50.25 \pm 3.16$ & $45.5 \pm 1.39$ & $38.75 \pm 4.05$ \\
3 & Sand\% & $15.25 \pm 1.91$ & $26.5 \pm 1.0$ & $20.75 \pm 4.28$ \\
& Class & Silty loam & Silty clay & Silty clay \\
\hline
\end{tabular}

\section{Bulk Density/BD}

The soil lab analysis showed that, the mean amount of BD of enset field and annual crop field were $1.2 \mathrm{~g} / \mathrm{cm}^{3}$ and 1.3 $\mathrm{g} / \mathrm{cm}^{3}$, respectively (Table 3). Enset field has low $\left(1.2 \mathrm{~g} / \mathrm{cm}^{3}\right)$ $\mathrm{BD}$ with no significant difference at $(\mathrm{P}<0.05)$ level. BD describes the potential for leaching, productivity, and erosion.

Any practice of cultivating enset could improve soil structure. However, in some cases these improvements may not be sustainable at the time of scraping it, because of labour movement which may compress the soil. However, according to the [16], all the sampled soils were categorized in to the low rank (1.0 to 1.3). It indicates that these soils are structurally good because it has low bulk density and high pore space to aeration and infiltration.

In the beginning of the rainy season and after maturation, annual crops have little root proliferation and little effect on nutrient leaching. For established enset, roots already proliferate in the soil profile at the beginning of the rainy season [18]. It makes the environment favourable for plant and crop roots, which in turn increases soil fertility in general. According to [23], loose porous soils and those rich in organic matter have lower bulk densities which agree with this study. 
The large mass of the plant should serve as a storage reserve, reducing the availability of the nutrients in the soil for leaching [18].

The mean value of BD was $1.26 \mathrm{~g} / \mathrm{cm}^{3}, 1.12 \mathrm{~g} / \mathrm{cm}^{3}$, and 1.22 $\mathrm{g} / \mathrm{cm}^{3}$ for dega, w/dega and dry w/dega AEZs (Table 4). ANOVA revealed that no significant difference in amount of $\mathrm{BD}$ in different AEZs. Multiple comparison test using the tamhane also used showed that, no significant difference in each AEZs.

\section{Soil Texture}

Soil texture is another important physical property of soil. It indicates the potential rate of infiltration, water-holding capacity, degree of leaching and erodibility of the soil [20]. Laboratory analysis of soil has shown that average size of clay, silt and sand fraction under enset cultivation was $31.2 \%, 49.3 \%$ and $19.5 \%$, respectively, while in the annual crop land the proportion of clay, silt and sand were $37.5 \%, 40.3 \%$ and $22.2 \%$, respectively (Figure 4 ).

The mean value of textural classes was different on the enset and annual crop lands that is given in figure 4 .

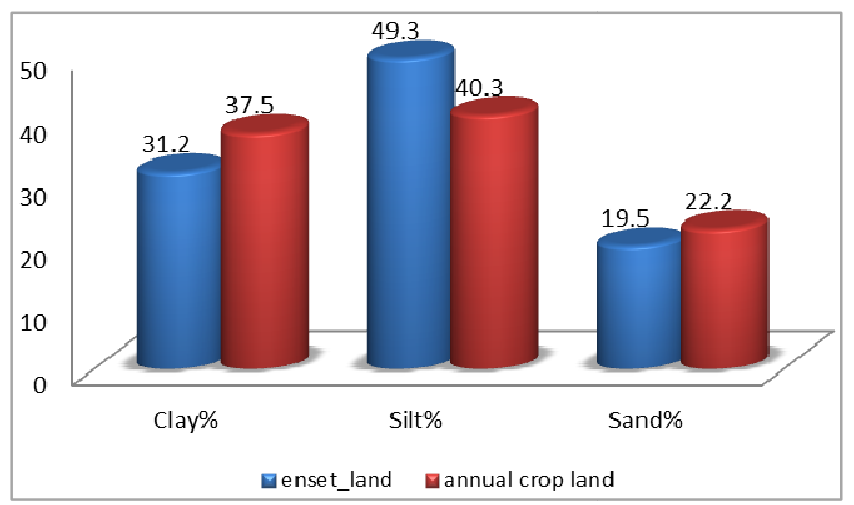

Figure 4. The mean value of textural classes on the enset and annual crop lands.

Based on the USDA soil texture triangle chart reading the above soil textural classes in the enset and annual crop land were silt clay loam and clay loam, respectively (Table 3). Based on this it is possible to suggest that both plots (enset and annual crop land) have good soil textural class. These are highly desirable for cultivation of many crops because it can stand drought and unsuitable condition and/or it has low evapotranspiration. Sometime organic substances are applied to the modified soil and have better physical characteristics, such as water holding capacity [18]. When compared to the sandy soils both have the ability of water holding capacity.

Figure 17 show that annual crop land (37.5\%) has high amount of clay than enset $(31.2 \%)$. However, clay cannot easily release water to the crops. Even clay soil has an ability to hold water so tightly that it is not easily available for plants [1]. By using soil textural triangle the soil class of dega, $w / \operatorname{deg} a$ and $d r y w / \operatorname{deg} a$ were silty loam, silty clay loam and silty clay, respectively.

\subsection{Conservation of Soil and Water by Using Enset Crop}

According to the survey, about $86.8 \%$ of respondents indicated that enset is used to conserve soil and water. From all sampled household almost all were the users of enset to protect and reduce land degradation and soil erosion in addition to food source. This could be due to conservation tillage by enset canopy leaf, litter and long roots. Conservation tillage is one of the components of sustainable agriculture, which is environmentally friendly. US Soil Conservation Service, defines conservation tillage as any tillage system that leaves at least $30 \%$ of surface covered by plant residues for control erosion by water; for controlling erosion by wind [17]. Furthermore, farmers favour mulching crops like banana and enset because they know that it suppresses weed growth, maintains soil fertility and conserves moisture for those shallow rooted crops [11, 21].

Based on the field observation and response of farmers, enset can reduce soil erosion and land degradation. This is similar with the work of [15] and he noted that enset protects the soil from erosion and degradation of soil because of its canopy leaves, abundant accumulation of litter and continuous application of manure. The root system and non-fertilizer cultivation are other important characteristics to protect soil erosion and land degradation. Some respondents noted that they cultivate enset in the face of flood and drain it in to enset farm in order to reduce further soil erosion.

Literatures shares the above concept as enset is an erosion barrier particularly when it is planted on the top of the farm [21]. About $85.5 \%$ of respondents revealed that enset crop can reduce soil erosion with its canopy leaves and long roots. Its funnel like leaves and spongy root systems form mate-like structure in the root zone that minimize soil erosion and run-off, which ultimately improve the water and nutrient budget of the sub unit [21].

In order to understand enset's role in protection of soil erosion and land degradation according to different parameters, the researcher forwarded different questions for farmers. According to this, soil fertility, other crop yield, food security of the household and sustainability of spring and borehole water could be increasing due to enset cultivation in their homestead. At the time of the survey, it has been commonly observed that species like enset, with deep roots and leaf canopies of long duration, improve the water status of an area.

Further other literature confirm that, as the proportion of these species increases with respect to annual species, water infiltration increases and surface runoff decreases, resulting in more water in the soil and aquifers. Enset crop could increase water availability and greater volume and duration of discharge to springs, decreasing the effective length of the dry season of the area [18].

\section{Conclusion}

Soil quality like total nitrogen, soil organic carbon and available phosphorus in enset field has a higher status than other crop fields. It indicates that enset cultivation is sustainable system with regard to maintain soil fertility significantly higher in the enset field. This might be due to the 
materials added to the soil from the plant parts and organic farming (application of manure and domestic waste). Enset has highly degradable parts such as leaf midribs, pseudostem sheath, pseudostem core/ which are used to maintain soil fertility.

Any practice of cultivating enset could improve soil structure. However, in some cases these improvements may not be sustainable at the time of scraping it, because of labour movement which may compress the soil.

Enset can reduce soil erosion and land degradation. The root system and non-fertilizer cultivation are other important characteristics to protect soil erosion and land degradation. Some farmers cultivate enset in the face of flood and drain it in to enset farm in order to reduce further soil erosion.

\section{References}

[1] Alemayehu Assefa, "Impact of Terrace Development and Management on Soil Properties in Anjeni area, Eest Gojam." MSc. Thesis. Addis Ababa University, Addis Ababa, 2007.

[2] C. García, A. Zsolnay, and M. Kuderna, "Soil Rehabilitation: Indicators and Thresholds for Desertification, Soil Quality, and Remediation." Sixth framework programme (global change in ecosystems), 2004

[3] D. Fekadu and I. Ledin, "Weight and chemical composition of plant parts of enset (Enset ventricosums) and the intake and degradability of enset by cattle." Livest. Prod. Sci. 49(3): 249-257, 1997.

[4] E. Akinrinde, "Soils: Nature, Fertility Conservation and Management." (V. Chude, M. Amakiri,..eds). AMS Publishing, Ibadan, 2004.

[5] EFAP, "The Challenge for Development." Vol. II, Final Report. Ministry of Natural Resources Development and Environmental Protection. Addis Ababa, 1997.

[6] Elias Eyasu, "Soil enrichment and deletion in southern Ethiopia." In: Nutrients on the Move: Soil fertility dynamics in African farming systems, Pp 65-82 (T. Hillhorst, and F. Muchena., eds), 2000.

[7] H. Zhang and G. Zhang, "Landscape-scale soil quality change under different farming systems of a tropical farm in Hainan, China." Soil U. Manag. 21: 58-64, 2005.

[8] ICARDA, "soil and plant analysis laboratory manual." www.icard.org/publication/lab:Data accessed: March 05, 2013, 2005.

[9] J. R. Landon, "Tropical Soil Manual." A handbook of soil survey and agricultural land evaluation in the tropical and subtropical. Longman. Broaker, Pp. 447, 1991.
[10] K.J. Schlather, "The Dynamics and Cycling of Phosphorus in Mulched and un Mulched Bean Production Systems Indigenous to the Humid Tropics of Central America." Ph.D. Dissertation, Cornell University, New York, 1998.

[11] M. Bekunda, "Farmers' response to soil fertility decline in banana-based cropping systems of Uganda." Man. Afri. Soils 4:1-17, 1997.

[12] M. A. Stocking, "Tropical Soils and Food Security: the next 50 years." Science 302: 1356-1359, 2003.

[13] Mekuria Argaw, "Forest conversion - soil degradation - farmers perception nexus: Implications for sustainable land use in the southwest of Ethiopia." In: Ecology and Development. (Vlek, P. L. G; Denich, M.; Martius, C.; Rodgers, C.; Giesen, N. V. D., eds.), 2005.

[14] N. Brady, and R. Weil, "The Nature and Properties of Soils, $13^{\text {rd }}$ edn. Prentice Hall. Upper saddle river, New Jersey. pp960, 2002

[15] P. Peveri, "Enset, the Tree of the Poor." Nutrition and identity in Hadiya zone (south-central Ethiopia).University of Bologna, Bologna, 2011.

[16] P. A. Hazelton, and B. Murphy, "Interpreting Soil Test Results." What do all the numbers mean? $2^{\text {nd }}$ edn, CSIRO publishing, Australia, 2007.

[17] R. Miller and R. Donahue, "Soils in Environment." $7^{\text {th }}$ edn. Prentice Hall of India, New Delhi, 1997

[18] S. A. Brandt, A. Spring, C. Hiebsch, S. T. McCabe, T. Endale, D, Mulugeta, W/M. Gizachew, Y. Gebre, M. Shigeta, and T. Shiferaw, "The 'Tree Against Hunger'. Enset-based Agricultural Systems in Ethiopia." American association for the advancement of science, Washington, DC, 1997.

[19] Tadesse Kippie, "Five Thousand Years of Sustainability? A case study on Gedeo land use, Southern Ethiopia." Treemail publishers, Heelsum, Netherlands, 2002.

[20] Teshome Yirgu, "Assessing Soil Nutrient Depletion to Household Food Insecurity in the Smallholders Farming System in the Western Hills of Lake Abaya." Ethio. J. Env and E. Sci. 2(4), 2012.

[21] Tilahun Amede and Mulugeta Diro, "Optimizing soil fertility gradients in the Enset (Ensete ventricosum) systems of the Ethiopian highlands: Trade-offs and Local Innovations." In: Improving Human Welfare and Environmental Conservation by Empowering Farmers to Combat Soil Fertility Degradation (Bationo et al., eds). African highlands initiative (AHI), working papers No 15, 2005.

[22] UNEP, "Environment and Biodiversity Impact assessment." Field survey report, Hossana, 2012.

[23] USDA, "Soil quality indicators." USDA, Natural Resources Conservation Service, Nyle, 2008. 